\title{
Clio
}

Women, Gender, History

37 | 2013

When Medicine Meets Gender

\section{Male and female bodies according to Ancient Greek physicians}

Jean-Baptiste Bonnard

Translator. Lillian E. Doherty and Violaine Sebillotte Cuchet

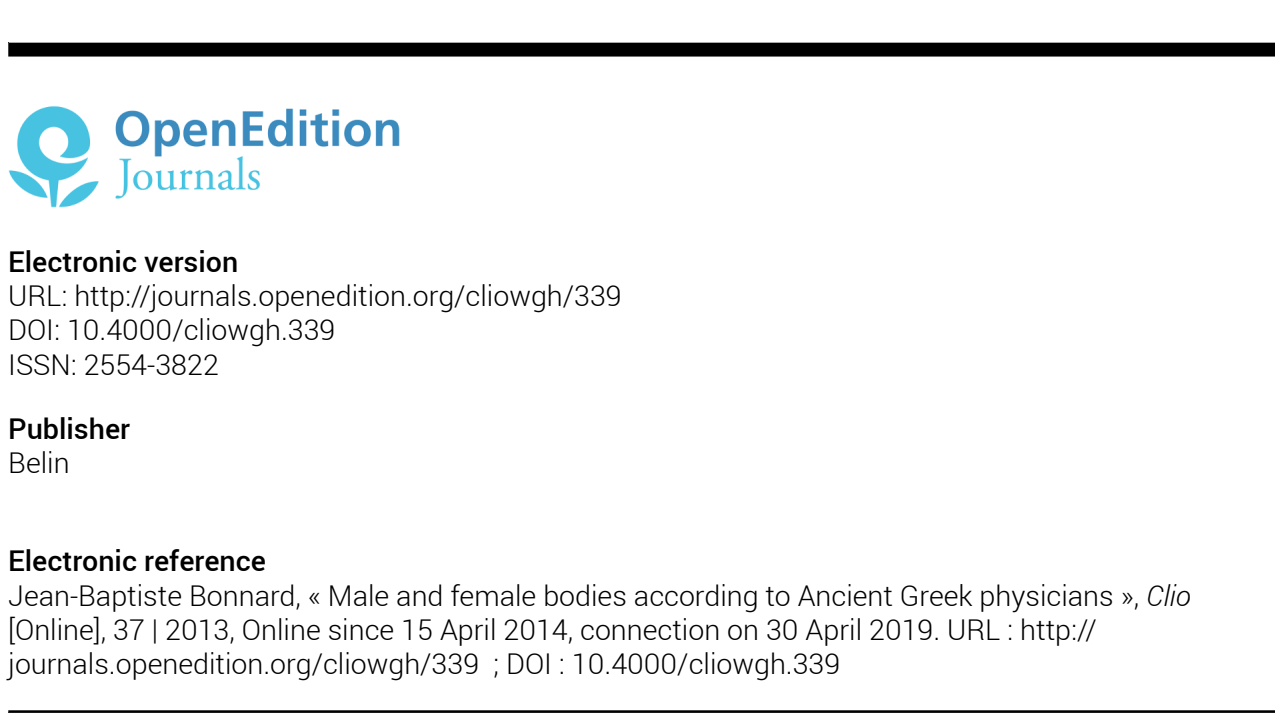

Clio 


\title{
Male Body and Female Body in Greek Medicine
}

\author{
Jean-Baptiste Bonnard
}

If health and sickness belong to a universally shared experience, the ways in which they are lived, and a fortiori the ways of treating the questions they pose - to the individual as to the society - vary from age to age and from place to place. It is one of the distinctive features of Greek thought to have given, before any other western tradition, a rationalistic response to these questions. It was in the Greek world, in fact, that at the end of the archaic age, medicine was established as a technè, a term that can be translated simultaneously as "art" and "science."1 This evolution took place principally in Ionia and is inseparable from a broad intellectual movement that affected many areas of knowledge. It was in this region that in the space of two or three generations there flourished most of the thinkers whom $19^{\text {th }}$ century historiography classified as "Presocratic philosophers," although strictly speaking not all were chronologically prior to Socrates, and although in many ways they can rather be considered 'learned men' or 'scholars', savants. As the ancient term for them, physiologoi (or physikoi), indicates, they produced a logos, i.e. a rationalistic discourse, on nature (phusis) in general. Geoffrey Lloyd has shown that the emergence of this rationalistic discourse was inseparable from the rapid development and professionalization of the practice of rhetoric; this phenomenon in turn, according to the hypothesis of Jean-Pierre Vernant, was related to a major political development, the emergence of the polis. ${ }^{2}$ The proximity of some of these Greeks of Asia Minor to eastern cultures (Babylonian and Egyptian in particular) must also have played a decisive role. These

\footnotetext{
For a clear basic introduction to ancient medicine, see King and Dasen 2008.

2 Lloyd 1983 and 1990; Vernant 1962 and 1965.
} 
thinkers' vast field of study - nature as a whole, as the title often given to their works, On Nature, indicates - led them to take an interest in areas as far apart, to our way of thinking, as astronomy, physics, biology, or mathematics, all interrelated because they belong to a common current of philosophic thought. At the beginning of the classical era, the production of this rationalistic thought underwent a form of specialization. Just as the field of history became autonomous with the work of Hecataeus of Miletus and most importantly Herodotus of Halicarnassus, that of medicine was formed and associated with the name of Hippocrates of Cos (ca. 460370). There is no reason to doubt the historical existence of this physician and author, born into a family of Asclepiadai (i.e., a lineage claiming descent from the god Asclepius, associated with medicine) in which medical knowledge was transmitted. But this is by no means to say that he was the author of all the works handed down under his name. The sixty-odd works in Ionic dialect that form the Hippocratic corpus were in fact written between the second half of the fifth century BCE and the Roman era, and with the exception of two that are in some sense "signed," the authors of these works are unknown to us. So it is for the sake of convenience and by convention that we speak of the Hippocratic corpus or collection. This series of treatises, which is far from comprising the majority of Greek medical literature, is important not only for its novelty but for its foundational character. It contributes greatly to the construction of a professional identity for the physician (especially the treatise entitled On the Physician). In particular, it provided the framework for western medical thought until the eighteenth century. Finally, it is of considerable interest for the historian of gender. Medical discourse speaks primarily of an object that has a sex, the body, but although it takes a rationalistic form, Greek medical discourse is nonetheless an ideological construction, like all scientific (or in this case, prescientific) discourse, as has been shown by, e.g., Delphine Gardey and Ilana Löwy. ${ }^{3}$ I propose an account of the way in which Greek biological and medical texts contributed to the fashioning of the categories of male/masculine and female/feminine by contructing a

3 Gardey and Löwy 2000. 
male body and a female body. While based on the Hippocratic corpus, this study aims to consider the majority of Greek biological and medical writings. Thus Aristotle, for example (himself the son of a physician), whose curiosity extended to nearly all fields of knowledge and who applied to all disciplines the rigor of his logical analyses, was greatly occupied with biology, to the point that his biological treatises constitute nearly a third of the surviving Corpus Aristotelicum, and some have seen him as a founder of the science of biology. ${ }^{4}$ Among the Greek physicians whose writings have come down to us in part, we will also consider Herophilus and Erasistratus, who lived in Alexandria at the beginning of the Hellenistic era, as well as Soranus of Ephesus (early second century CE) and Galen of Pergamon (129-216). Even thus delimited, the corpus is extensive, and the approach of gender studies has been applied to it for about thirty years, notably in the English-speaking world. This has resulted in an already sizeable bibliography, of which I propose to give a synthetic and dynamic overview. Ancient Greek biology 5 and medicine as a whole conceive of male and female bodies as profoundly different. This difference is both a given from the beginning (in utero) and an ongoing, never-finished process.

\section{Construction of the female and male in embryogenesis and the development of the fetus}

The physiologoi of the late archaic and early classical periods took an interest in biology or medicine and some of them (Empedocles, Pythagoras, Alcmaeon and Philolaus of Croton, Archelaus, Democritus of Abdera, Hippo of Samos and perhaps Diogenes of Apollonia) can be considered physicians or were accepted as such. They were especially preoccupied with the question of generation, reflecting on the origin of "seed," on whether or not a maternal "seed" existed, on the formation of the embryo (and more specifically on the determination of its sex), and on heredity. Since their books

4 Byl 1980.

5 I use this term for linguistic convenience, although biology as a discipline does not exist in the ancient Greek world. The term itself is not part of the ancient Greek vocabulary; it was a neologism coined in the nineteenth century. 
have not come down to us, it is difficult to reconstruct their thought. It is only by means of multiple intermediaries, and in particular thanks to Aristotle's critiques of them, that we can arrive at an understanding - very partial and decontextualized-of their doctrines. It seems that the theories of these thinkers have in common that they place the male and female principles in opposition to each other, coupling them with attributes such as heat and cold (Empedocles), fast and slow, strong and weak, right and left (Parmenides), which are given positive or negative connotations. ${ }^{6}$ Moreover, the theories seem clearly to imply that the most desirable situation is the production and then the birth of a boy who resembles his father. ${ }^{7}$

In contrast to most of their Presocratic predecessors, the Hippocratic physicians admitted the existence of a maternal seed that participated in the process of generation. Several Hippocratic treatises are concerned with embryogenesis and the development of the fetus, notably The Seven-Month Fetus and The Eight-Month Fetus, two short works published separately in the ancient editions but forming in reality a single treatise devoted to embryology, and dating from the end of the fifth century BCE or the beginning of the fourth. ${ }^{8}$ The most complete work in this area is On the Nature of the Child, a continuation of $O n$ Generation (a single treatise of the late fifth/early fourth century which was artificially split in the manuscript tradition). This treatise contains the affirmation that male fetuses, which are stronger, are more rapidly formed than female fetuses: "Here is the child already formed: the girl reaches this point in forty-eight days, the boy in thirty days at most."' According to the same logic, male fetuses quicken sooner:

6 For a detailed analysis of the biological theories of these thinkers, see Bonnard 2004, ch. 4.

7 Bonnard 2006: 308-312.

8 See especially Hanson 1992a.

9 Hippocrates, On the Nature of the Child, 18.1. Unless otherwise indicated, translations are based on the French in the Collection des Universités de France (Belles Lettres), or for Hippocratic texts not in the CUF collection, that of Littré. 
When the extremities of the child's body have branched out externally and the nails and the hair are rooted, it begins to move; this happens for the boy at three months and for the girl at four. (Nature of the Child 20.1)

The explanation for this chronological differentiation in embryogenesis is to be sought in the set of correlations already observed in the Presocratics:

The boy moves sooner because he is stronger than the girl, just as he coagulates sooner, because the male originates in a stronger and thicker seed than the female.

We should not therefore be surprised to see that the sex of the embryo she carries is described as having important repercussions for the future mother. As another contemporary treatise says (Diseases of Women 216 = Sterile $W$ omen 4$)$ :

The women who while pregnant have spots on their faces are carrying a girl, while those who have a good complexion are most often carrying a boy; when the nipples are turned upward, it is a boy; when turned downward, a girl.

This downward orientation of the nipples must have negative connotations, since elsewhere a Hippocratic aphorism makes it a sign of spontaneous abortion in a woman carrying twins. ${ }^{10}$ In general, "a pregnant woman has a good color if she is carrying a boy, bad if she is carrying a girl" (Aphorisms 5.42). The Aphorisms, one of the most famous treatises in the collection (the most often read and commented on, and one which served as a handbook for western physicians until the eighteenth century) is a compilation no older than the fourth century. It is traditionally divided into seven sections, the fifth of which includes several aphorisms on women.

Aristotle took a great interest in generation. His general conception of "seed" and of the process of generation is in keeping with three other aspects of his thought: the Aristotelian theory of the four causes (the mother being only the material cause of generation while the father is both its formal and efficient cause); a general economy of interchangeable body fluids; and the prescientific assumption which Bachelard called the myth of the concentration of

$10 \quad$ Hippocrates, Aphorisms 5.38. 
substance. The woman produces a seed that only serves as food for the embryo. The fashioning of the embryo is a form of coction that in a famous metaphor Aristotle compares to the curdling of milk. ${ }^{11}$ Aristotle's theories on heredity are quite complex and rather confused. ${ }^{12}$ For the Stagirite, it is not only common but in a way desirable that the child resemble its parents, insofar as that belongs to the natural order of things: the birth of children who do not resemble their parents in their individuality may not come under the heading of teratology (the study of abnormality), but it constitutes a departure from the essence. It is very revealing, moreover, that in the context of his exposition of this general rule on the frequency of resemblances, and more precisely when he has just been speaking of teratological departures from nature, Aristotle arrives at the affirmation that "the first departure [from nature] is the birth of a female instead of a male."13

We have little information about what the Alexandrian physicians knew about theories of generation. We have only indirect and fragmentary information about Herophilus of Alexandria (ca. 325 ca. 255), who studied medicine, probably in Cos, and taught at Alexandria, the cultural and scientific capital of the Greek world of his day. Thanks to the work of Heinrich von Staden, we nonetheless have an idea of his opinion on the present topic. ${ }^{14}$ In regard to male seed, we know more about his understanding of its circulation in the male genital organs than about his view of spermatogenesis. At the most we recognize that like Aristotle, Herophilus thought that sperm came from blood. Doubtless, Herophilus had more to say about female seed in his Obstetrics, but this work is almost entirely lost.

The Greek physicians of the second century of our era are particularly important because they have had an enduring influence. Soranus of Ephesus, who can be considered the genius of ancient

11 Aristotle, $G A$ 1.20.729a 11-13; 2.3.737a 15; 2.4.739b 21-26; 4.4.771b 23-27; 4.4.772a 23-25.

12 See Joly 1968 and Bonnard 2006, 313-318.

13 Aristotle, GA 4.3.767b 8. Cf. Aristotle, GA 1.20.728a 17-18; 2.3.737a 27-28; 4.6.775a 15-16; 5.3; and Probl. 10.8.891b 23.

14 See von Staden 1989, 291-296. 
gynecology, examined the formation and development of the embryo in a lost work intitled $O n$ Generation and in the first book of his Diseases of Women. In addition to his personal experience, he relies on a magisterial knowledge of the medical literature and levels serious criticisms at some of his predecessors. A propos of the Hippocratic assertions about the external signs by which it was thought possible to recognize the sex of a pregnant woman's child, Soranos described these as opinions "based on belief rather than truth" (Diseases of Women 1.15) and noted that they were belied by common experience. ${ }^{15}$ He nevertheless believed that the principle of generation resided in the male. In his view, only the sperm is active. Its mobility permits it to enter the uterus, where it is retained and can coagulate to form an embryo. To be sure, the woman emits a kind of seed, ${ }^{16}$ but this is useless for generation and as a result is evacuated by means of the bladder:

The seminal duct, which begins in the uterus, passes through each ovary and after following the flanks of the organ as far as the bladder, empties into the neck of the latter. Observations indicate that the female seed does not seem to be collected for the purpose of conception, since it is discharged externally; I have taken a position on these facts in my treatise On Seed (Diseases of Women 1.4.93-98).

Finally, Galen of Pergamon devoted to embryology several of the hundreds of treatises he wrote in the course of his long career: $D e$ semine, De uteri dissectione, De foetuum formatione, De septimestri partu. In spite of his reverence for Aristotle, he has the idea that the woman produces a seed useful for generation; but it is nonetheless inferior to the male sperm, notably in terms of agility and heat. For him too, the creative principle resides in the male sperm, and when Galen reflects on the determination of the embryo's sex, he adopts an explanation based on the criterion of sides: if the seed falls into the right side of the uterus it will give birth to a boy, but on the left a girl. In this criterion we see once more the prejudices we noted in the Presocratics, whose positive and negative connotations have long

\footnotetext{
15 Gourevitch 1992, 597-598.

16 Gerlach 1938, 186.
} 
been shown by anthropologists. ${ }^{17}$ The construction of female/feminine and male/masculine by the ancient Greek physicians thus begins with the fetal stage. It continues for the rest of the life course.

\section{A medicine based on physiology: the economy of bodily fluids and the production of female and male}

One of the peculiarities of Hippocratic medicine is the importance it gives to physiology at the expense of anatomy; the latter can thus look like a still-embryonic branch of Greek medicine, of which the Hippocratic corpus gives no systematic description. ${ }^{18}$ Instead, the corpus puts forward an explanatory system of physiology based on a general economy of bodily fluids, one of whose best-known aspects is the theory of the humors (anticipated as early as the work of the $6^{\text {th }}$ century physician Alcmeon of Croton, a Pythagorean). The Hippocratic theory of the humors is not itself unified; important differences are to be found among the treatises, and in particular on the question of the number and qualities of the humors. ${ }^{19}$ In this system, internal medicine considers the different organs as so many containers, which is why Robert Joly described this medicine as "a physics of the container." 20

In this context, the male and female bodies are clearly contrasted according to criteria that carry connotations; in particular, the woman's body is more moist than the man's. ${ }^{21}$ But this difference in moisture is presented as an excess in relation to the norm of the happy medium, the mesotes, which is the privilege of the male body. ${ }^{22}$ In fact, the abnormal female body is almost always thought of by

17 Gerlach 1938, 188 and Boylan 1986. On the respective value of the right and left from an anthropological perspective, see Hertz 1909.

18 See Di Benedetto 1986, 225-247, and Bratescu 1992.

19 See Jouanna 1992, 442-445, and on the afterlife of this theory, Klibansky, Panofsky and Saxl 1989, 31-45.

20 Joly 1966, 75-80.

21 See Girard 1983 and Hanson 1992b, 48-52 (“IV. Manipulating the Wet”).

22 On the female body deprived of mesotés, see Manuli 1980, 402 and Hanson $1992 b, 245$. 
comparison to a normative male body, as the analogies used by the Hippocratic physicians show; for example, "If the uteri fall completely outside the genitals, the ensemble hangs like a scrotum." 23 It should be added that Geoffrey Lloyd has demonstrated the importance of analogical reasoning in the whole of Greek thought, not only in medical thought. ${ }^{24}$ The variation in the amount of moisture, which is found even in the texture of the flesh -- that of women being thought of as spongier than that of men ${ }^{25--}$ is linked to the quantity of blood in their bodies, which is represented (incorrectly, since the opposite is true) as more abundant in the woman than in the man from puberty onwards. ${ }^{26}$ The menses, whose exact composition was not understood, were thought necessary to evacuate the excess moisture. Much attention was paid to the menses. ${ }^{27}$ Their absence, outside of pregnancy, was considered morbid, very worrisome, and often a forewarning of hemorrhages. ${ }^{28}$ The alternative menses/hemorrhage can be seen especially in the Prorrbetikon, a collection of clinical aphorisms attributable to an itinerant physician who probably lived in the mid fourth century: "Tremors in the head and ringing in the ears produce a hemorrhage or precipitate menstruation." 29 In the least pernicious cases, amenorrhea is thought to produce epistaxis (nosebleed): according to the Aphorisms, "In a woman who does not menstruate, it is good for the blood to flow out through the nostrils." 30 The absence of menses may signal a stasis of the blood in another container-organ, with harmful consequences. Thus "in women, a congestion of blood in the breasts is a sign of impending madness." 31 Conversely, the return of menses is a sign of healing and one of the physician's objectives.

\footnotetext{
23 Hippocrates, Nat. mul. 5. See Manuli 1980, 393.

24 Lloyd 1966.

25 King 1998, 28-29.

26 Hanson 1992b, 247.

27 Dean-Jones, 1989; id.1994, 86-103; Bodiou 1999; id. 2006, 153-157.

28 Manuli 1980, 402; Hanson 1992b, 236; and Bonnet-Cadilhac 2002.

29 Hippocrates, Prorrh. 1.143.

30 Hippocrates, Aph. 5.33. The case of Leonides' daughter (Epid. 7.123) is seen as an exception that proves the rule. On this subject see King 1998, 54-74.

31 Hippocrates, Aph. 5.40.
} 
But their presence in "bad" amounts or appearance, as in the case of displacement of the uterus or of its orifice, is also considered very negative: "If the uteri move toward the hip, the menses stop," and "If the orifice of the uteri withdraws, the menses do not come, and if they come, they are sparse and bad," according to the treatise On the Nature of the Woman. ${ }^{32}$ In this context of the physiology of containers and humors, the woman's body is distinguished by its remarkable faculty of intercommunication between organs: from the mouth to the vagina by way of the uterus, liquids - but also vapors or fumes can and should circulate freely. ${ }^{33}$ The male body does not have these problems of excessive moisture and as a result is protected against certain diseases, except in the case of men whose constitution does not conform to the perfect type of their gender, as two aphorisms indicate: "If the winter is dry and boreal and the spring rainy and austral, there will necessarily follow in summer acute fevers, ophthalmia, and dysentery, especially in women, and among men in those whose constitution is moist;" "but if the autumn is boreal and without rain, it is good for men of moist constitution and for women." 34 Thus while the female body is by nature subject to diseases because of its excessive moisture, the male body, as long as it is sufficiently masculine, is healthy and has no need to eliminate regularly any excess moisture. This is because it is less spongy and hotter.

Heat is another of the many polarities that structure this conception of female and male bodies. The greater heat of the male body is attributed, by altogether circular reasoning, to the fact that it is less moist. For Aristotle, this difference in vital heat also serves to explain spermatogenesis. For the Stagirite, whose physiological system is based on the postulate of the fungibility of all bodily fluids, semen comes neither from the brain via the marrow, as Plato, the Pythagoreans, and (probably) Empedocles thought, nor from all parts

32 Hippocrates, Nat. mul. 8 and 7. On menses that are too copious or too sparse, see King 1998.

33 Hanson 1992b, especially 239.

34 Hippocrates, Aph. 3.11 and 14. On the homology between women and "moist" men, see Dean-Jones 1994, 123. 
of the body, as the atomists and the Hippocratic physicians claimed, but rather from the blood-or rather, the hot part of the blood, aerated like foam, hence the white color of sperm. Just like milk, the menses, or fat, the seed, passing through the intermediate stage of blood, is a "useful residue" (perittôma) of food. It is in fact the most subtle, concentrated, and complete of the residues of food, that which has undergone a coction of superior quality and intensity, "a residue of food in its final degree of elaboration." 35 Such a coction could only be produced by a perfectly hot body. This is why the blood of women, who are colder by nature, produces a residue that is insufficiently cooked, useless unless the woman is pregnant, and thus voided by the menses. If the woman is impregnated, this residue provides only the matter of the embryo, the nourishment for the fetus during the pregnancy, and finally the milk after the birth. The difference in the quality of the residue at once puts the male and female in a hierarchical relationship:

This is why, wherever possible and to the extent possible, the male is distinct from the female. For the principle of movement, i.e. the male, is the best and most divine thing for beings who are born, while the female is the matter. ${ }^{36}$

The male body, a perfect machine, is alone capable of producing the sperm, a perfect product.

The difference between the sexes is thus not, for these writers, merely a polarity; it derives from a difference of nature, resulting from a process that continues throughout the life course. It results in a vicious cycle in the female body, where the excessive moisture is maintained, and in a virtuous cycle in the male body, where -- except in case of illness or constitutional defect -- the proper equilibrium between heat and cold, moisture and dryness, persists and continually renews masculinity. This difference of nature is still more visible in the branch of Hippocratic medicine concerned with female anatomy: the gynecological treatises.

\footnotetext{
35 Aristotle, G.A. 1.18.726a 26-27.

36 Aristotle, G.A. 2.1.732a 6-9.
} 


\section{The distinctive features of female anatomy and the importance of the uterus}

Although Hippocratic medicine is essentially physiological, a part of the Hippocratic corpus nonetheless gives some attention to female anatomy. Known as the Hippocratic gynecological treatises, these are of different eras; the majority are attributed by the tradition to the Cnidean school of medicine. They represent the female and male bodies as profoundly dissimilar. The essential difference between the two anatomies is the existence in the woman of a supplementary container-organ, the uterus, whose distinctive feature is to be perceived as a sort of mobile living creature. It is animated, actually endowed with movement, and in particular can open or close. It is naturally inclined to move toward sources of moisture. Some of its movements are attributable to its will, for it is endowed with a will of its own. Thus the treatise on The Nature of Women explains, in regard to a case of prolapse, that the uterus "no longer wants to return to its place." 37 This gluttonous zôon inside another animal, i.e., the female body, ${ }^{38}$ is avid to conceive. ${ }^{39}$ Plato, a contemporary of Hippocrates and acquainted with him, develops this aspect in the Timaeus: "That which in women we call for the same reasons matrix and uterus is an internal animal subject to the desire to make children." 40 This conception leads to the idea that the female body is structurally hysterical, ${ }^{41}$ and that is certainly the way Plato represents it:

When [the uterus] has remained sterile for a long time after having passed the suitable age, this organ becomes impatient; it does not accept this state, and because it begins to wander throughout the body, obstructing the orifices by which the breath goes out and preventing respiration, it throws the body into the most extreme states and provokes illnesses of all kinds. ${ }^{42}$

This takes us back to the very distinctive perspective in which the female body is nearly always seen: with reproduction as its goal. ${ }^{43}$ Evidence for this view is to be found in the vocabulary used by the corpus when it speaks of the woman's body even outside the

\footnotetext{
37 Hippocrates, Nat. mul. 5.

38 King 1998, 222-231; Bodiou 1999, 65-85.

39 Rousselle 1980, 1098 and Dean-Jones 1994, 65-79.

40 Plato, Timaeus 91c, based on the translation of J.-B. Bonnard. See Krell 1975 and Bonnard 2004, ch. 6.

41 Manuli 1980, 397.

42 Plato, Timaeus 91c, based on the translation of L. Brisson.

43 Manuli 1980, 394; Rousselle 1980, 1092; Dean-Jones 1994, 47.
} 
gynecological treatises, ${ }^{44}$ as well as in the metaphors used by the Hippocratic gynecologists. ${ }^{45}$ The contrast with the male body is clear; the latter is never considered in this perspective alone. As for Aristotle, who clearly knew more about the anatomy of female animals than of women, he has left us no description of the female human body, which would have had little utility for him in any case, since his objective is not medical.

Herophilus, by contrast, clearly had more extensive knowledge of anatomy than his predecessors, especially due to human dissection, which he seems to have been the first to practice in the Greek world. He even practiced vivisection on criminals condemned to death, if we are to believe the possibly malicious testimony of the Latin encyclopedist Celsus (1.21), who lived at the beginning of the Christian era. But while it is almost certain that he identified, in the human reproductive apparatus, the spermatic canal, the ovaries, and the Fallopian tubes, it is unlikely that he understood their workings. ${ }^{46}$ His discoveries, taken up by his successors, notably Demetrius of Apamea, and probably enlarged upon by the use of the speculum, are nonetheless important and opened the door to a reconsideration of the difference of nature between male and female bodies. In fact, these discoveries obliged the physicians of the Roman era to undertake laborious readjustments of their doctrines. ${ }^{47}$ It is significant, nonetheless, that he represents the organs of generation in the woman according to the model of the male body, contributing to the construction of what Thomas Laqueur has called the model of the unisex body. 48

Four centuries later, Soranus took an interest in female anatomy and more specifically in the uterus in the first book of his Diseases of Women. ${ }^{49}$ Although he still thinks of it as a living container, hence the

44 See, for example, Zaragoza-Graz 1992 on the Epidemics, especially on the verb tiktô ("give birth").

45 Hanson 1992a, 36-41 ("II. Analogs for the Adult Female: Mother Earth and the Upside-Down Jar").

46 Von Staden 1989, 165-168.

47 Hanson 1991a.

48 Laqueur 1992.

49 See Soranus, Gyn. path. 1.4 and Malinas, Burguière \& Gourevitch 1985, 161-165. 
source of uterine contractions, he does not attribute an autonomous will to it and makes fun of the physicians who equated it with a wild animal (3.5). Soranus' presentation of the female body, translated into Latin by Celius Aurelian and Moschion, was to become the bible of gynecology for centuries. Galen, one or two generations later, picked up and developed the medical concepts of his predecessors in a synthetic and critical spirit, with a clearly Aristotelian orientation. Drawing on the anatomical discoveries of the Alexandrian physicians, he interpreted the female body in light of the male body. The difference between the sexes is seen in the development of the reproductive organs: those of women are identical to those of men (analogies are drawn between the ovaries and testicles, between the uterus and the scrotum); 50 they have simply remained inside the body due to a lack of vital heat. Anatomy is thus merely a reflection of a difference between the sexes which originates in physiology; but this difference is now only a difference of degree and is no longer thought of as a difference of nature. Thus the woman differs from the man only in a lesser perfection:

Just as the human species is the most perfect of all the animals, within the human the man is more perfect than the woman, and the reason for his perfection is his greater heat, for heat is the first instrument of nature. ${ }^{51}$

While for Aristotle female nature was a mutilated kind of male nature and more or less monstrous, perceived in any case as very negative, for Galen its relative incompleteness is positive. In a teleological perspective, the Pergamene physician sees in it the design of nature: to permit the assurance of reproduction.

The model of the unisex body studied by Thomas Laqueur was thus constructed beginning with Aristotle and formalised by Galen, who simply substituted a hierarchy of degree to a hierarchy of nature. Beginning in Antiquity, this hierarchy of bodies has had direct implications for medical practice. It is reflected in a gendered construction of the classification of diseases and of therapies,

\footnotetext{
50 Galen, De sem. 2.1 (= K. 4, 596).

51 Galen, Ut. part., K. 2.630 (trans. based on Laqueur 1992).
} 
especially since the vast majority of doctors were men. Ancient theories on the female and male bodies are of considerable importance because they have had a long afterlife. With the advent of Christianity, theological considerations are intertwined with them, since Eve is thought to have arisen from an excess rib of Adam (at least in one of the versions given in Genesis). Throughout the medieval period and part of the modern era, medicine considered the two bodies in a hierarchical relation, perceiving the female body as more or less handicapped by comparison with the male body, because of its moisture, its insufficient heat and its disturbing uterus. As a medieval medical saying puts it, "The hottest woman is colder than the coldest man.”

Translated by Lillian E. Doherty

\section{Sources}

Note: This article was written before the decision to produce the online English version of Clio : the Greek sources are therefore listed here in their French editions.

[Aristotle], G.A: Aristote, De la génération des animaux, ed. and trans. Pierre Louis, Paris, Belles Lettres, 1961.

[Aristotle], Probl. : Aristote, Problemes, ed. and trans. Pierre Louis, Paris, Belles Lettres, 1991.

[Galen], De sem.: Galien, De semine, ed. Karl Gottlob Kühn, Hildesheim, G. Olms, 1997 (reprod. of vol. IV of Leipzig edition, 1821, cf. online edition: Paris, Bibliothèque Interuniversitaire de Médecine, Collection Médic@, 2003).

[Galen], Ut. part.: Galien, De uteri dissectione, ed. Karl Gottlob Kühn, Hildesheim, G. Olms, 1964 (reprod. of vol. II de Leipzig edition, 1821, also online: Paris, Bibliothèque Interuniversitaire de Médecine, Collection Médic@, 2003).

[Hippocrates], Aph. : Hippocrate, Aphorisme, trans. Émile Littré, Paris, J.-B. Baillère, 1844 (1973).

[Hippocrate], Épid. : Hippocrate, Épidémies V et VII, ed. and trans. Jacques Jouanna, Paris, Belles Lettres, 2000.

[Hippocrate], Nat. puer. : Hippocrate, De la nature de l'enfant, ed. and trans. Robert Joly, Paris, Belles Lettres, 1970. 
[Hippocrates], Nat.mul.: Hippocrate, Nature de la femme, ed. and trans. Florence Bourbon, Paris, Belles Lettres, 2008.

[Hippocrates], Prorrh.: Hippocrate, Prorrbétique, trans. Émile Littré, Paris, J.-

B. Baillère, 1861 (1973).

[Plato], Tim. : Platon, Timée, trans. Luc Brisson, Paris, Flammarion, 1992.

[Soranos], Gyn. path. : Soranos, Maladies des femmes, ed. and trans. w. notes by Paul Burguière, Danielle Gourevitch and Yves Malinas, Paris, Belles Lettres, 1988-2000.

\section{Bibliography}

Bodiou Lydie, 1999, «Histoires du sang des femmes grecques : filles, femmes, mères. D’après les écrits médicaux et biologiques ", thèse Rennes II.

—, 2006, « De l'utilité du ventre des femmes. Lectures médicales du corps féminin », in François Prost \& Jérôme Wilgaux (ed.), Penser et représenter le corps dans l'Antiquité, Rennes, Presses universitaires de Rennes, p. 153-166.

Bonnard Jean-Baptiste, 2004, Le complexe de Zeus. Représentations de la paternité en Grèce ancienne, Paris, Publications de la Sorbonne.

—, 2006, "Il paraît en effet que les fils ressemblent aux pères". Théories biologiques et médicales grecques dans le domaine de l'hérédité », in François Prost \& Jérôme Wilgaux (ed.), Penser et représenter le corps dans l'Antiquité, Rennes, Presses universitaires de Rennes, p. 307-318.

Bonnet-Cadilhac Christine, 2002, «Les aménorrhées dans le "Corpus hippocratique": la vision du médecin actuel», in Antoine Thivel \& Arnaud Zucker (ed.), Le normal et le pathologique dans la collection hippocratique. Actes $d u x^{0}$ colloque international hippocratique (Nice, 6-8 octobre 1999), Nice-Paris, Publications de la Faculté des Lettres, Arts et Sciences humaines de Nice - Sophia Antipolis, p. 575-589.

Boylan Michael, 1986, "Galen's Conception Theory », Journal of the History of Biology, xix/1, p. 47-77.

Bratescu Gheorghe, 1992, «Les rapports entre la physiopathologie et l'anatomopathologie hippocratiques", in Juan Antonio López Férez (ed.), Tratados hipocraticos (Estudio acerca de su contenido, forma e influencia), Actes du vii Colloque international hippocratique (Madrid, 24-29 sept. 1990), Madrid, Universidad nacional de educación a distancia, p. 171-179.

Byl Simon, 1980, Recherches sur les grands traités biologiques d'Aristote. Sources écrites et préjugés, Bruxelles, Académie royale de Belgique. 
Dean-Jones Lesley, 1989, «Menstrual Bleeding according to the Hippocratics and Aristotle », Transactions of the American Philological Association, cxix, p. 177-192.

—, 1994, Women's Bodies in Classical Greek Science, Oxford, Oxford Clarendon Press.

Di Benedetto Vincenzo, 1986, Il medico e la malattia. La scienza di Ippocrate, Turin, G. Einaudi.

Gardey Delphine \& Ilana Löwy, 2000, L'invention du naturel. Les sciences et la fabrication du féminin et du masculin, Paris, Éd. des archives contemporaines.

Gerlach Wolfgang, 1938, « Das Problem des “weiblichen Samens” in der antiken und mittelalterlichen Medizin», Archiv für Geschichte der Medizin und der Naturwissenschaften, xxx/4-5, p. 176-193.

Girard Marie-Christine, 1983, «La femme dans le corpus hippocratique », Cabiers des Études Anciennes, xv, p. 69-80.

Gourevitch Danielle, 1992, «Les lectures hippocratiques de Soranos d'Éphèse dans son traité Des maladies des femmes ", in Juan Antonio López Férez (ed.), Tratados hipocraticos (Estudio acerca de su contenido, forma e influencia), Actes du vii Colloque international hippocratique (Madrid, 24-29 sept. 1990), Madrid, Universidad nacional de educación a distancia, p. 597-607.

Hanson Ann Ellis, 1991, "The restructuring of female physiology at Rome ", in Philippe Mudry \& Jackie Pigeaud (dir.), Les écoles médicales à Rome. Actes du $i i^{e}$ colloque international sur les textes médicaux latins antiques (Lausanne, sept. 1986), Geneva, Droz, p. 255-268.

- 1992a, "Conception, Gestation, and the Origin of Female Nature in the Corpus Hippocraticum », Helios, xix/1-2, p. 31-71.

—, 1992b, "The logic of the gynecological prescriptions ", in Juan Antonio López Férez (ed.), Tratados hipocraticos (Estudio acerca de su contenido, forma e influencia), Actes du VIIe Colloque international hippocratique (Madrid, $24-29$ sept. 1990), Madrid, Universidad nacional de educación a distancia, p. 235-250.

Hertz Robert, 1970 [1 ${ }^{\text {st }}$ edn. 1909], «La prééminence de la main droite : étude sur la polarité religieuse », Sociologie religieuse et folklore, Paris, Presses universitaires de France, p. 85-107.

Joly Robert, 1966, Le niveau de la science hippocratique, Paris, Les Belles Lettres.

—, 1968, « La biologie d'Aristote », Revue philosophique, clviii, p. 219-253.

Jouanna Jacques, 1992, Hippocrate, Paris, Fayard.

King Helen, 1998, Hippocrates' Woman. Reading the Female Body in Ancient Greece, London - New York, Routledge.

King Helen \& Véronique Dasen, 2008, La médecine dans l'Antiquité grecque et romaine, Lausanne, Bibliothèque d'histoire de la médecine et de la santé. 
Klibansky Raymond, Panofsky Erwin \& Fritz Saxl, 1989, Saturne et la Mélancolie. Études historiques et philosophiques : nature, religion, médecine et art, Paris, Gallimard (French trans. of Saturn and Melancholy. Studies of natural Philosophy, Religion and Art, 1964).

Krell David Farrell, 1975, «Female Parts in Timaeus », Arion, II/1, p. 400-421.

Laqueur Thomas, 1992, La fabrique du sexe. Essai sur le corps et le genre en Occident, Paris, Gallimard (translation of Making Sex. Body and Gender from the Greeks to Freud, Cambridge Ma, Harvard University Press, 1990).

Lloyd Geoffrey Ernest Richard, 1966, Polarity and Analogy. Two Types of Argumentation in early greek Thought, Cambridge, Cambridge University Press.

—, 1990 [and 1996], Origines et développement de la science grecque : magie, raison et expérience, Paris, Flammarion (translation of: Magic, Reason and Experience. Studies in the Origin and Development of Greek Science, Cambridge, Cambridge University Press, 1979).

-, 1983, Science, Folklore and Ideology. Studies in the Life Science in Ancient Greece, Cambridge, Cambridge University Press.

Malinas Yves, Burguière Paul \& Danielle Gourevitch, 1985, «L'anatomie gynécologique de Soranos d'Éphèse », Histoire des Sciences Médicales, xix, p. 161 168.

Manuli Paola, 1980, «Fisiologia e patologia del femminile negli scritti ippocratici dell'antica ginecologia greca », in Mirko Drazen Grmek (ed.), Hippocratica. Actes $d u$ colloque hippocratique de Paris (4-9 sept. 1978), Paris, Éditions du CNRS, p. 393-408.

Rousselle Aline, 1980, «Observation féminine et idéologie masculine : le corps de la femme d'après les médecins grecs », Annales ESC, xxxv/5, p. 1089-1115.

Vernant Jean-Pierre, 1962, Les origines de la pensée grecque, Paris, Presses universitaires de France.

—, 1965, Mythe et pensée chez les Grecs. Études de psychologie historique, Paris, La Découverte.

von Staden Heinrich, 1989, Herophilus. The Art of Medicine in Early Alexandria, Cambridge, Cambridge University Press.

Zaragoza Gras Joana, 1992, «El léxico ginecológico de las Epidemias hipocráticas », in Juan Antonio López Férez (ed.), Tratados hipocraticos (Estudio acerca de su contenido, forma e influencia), Actes du viï Colloque international hippocratique (Madrid, $24-29$ sept. 1990), Madrid, Universidad nacional de educación a distancia, p. 479-489. 